\title{
Analysis Of Classroom Discourse And Instructor's Awareness Of Speech In A Spanish College Course
}

\author{
Graziela Rondon-Pari, Ph.D., SUNY College at Brockport, USA
}

\begin{abstract}
This is an instrumental case study and consists of the description, analysis and interpretation of the teaching practices of a Spanish college instructor. The aim of this research project is to find answers to the following questions: What is the ratio of L1-L2 spoken in class? For what functions is each language used? And, are there inconsistencies between teachers' beliefs and classroom practices in regards to the use of English and Spanish? Data were obtained from the tape recording of beginner level Spanish conversation classes in a private college in the Northeast. Other data sources included non-participant observations and an interview with the instructor. Results seem to indicate a prevalence in the use of English as opposed to Spanish in the classes observed. At the same time, there was an inconsistency between awareness regarding the use of English and Spanish in class and a prevalence of teacher talk compared to student speech.
\end{abstract}

Keywords: instructors beliefs; Spanish-English ratio; Spanish discourse analysis

\section{INTRODUCTION}

\begin{abstract}
Pearning a second language implies a complex cognitive process in which learners acquire foreign language proficiency through the exposure to different kinds of input, such as listening and reading. Output, mainly in the form of speaking, also plays an important role. Therefore, input is especially important when learning a foreign language, since there exists little opportunity for foreign language students for exposure to the target language outside the classroom.
\end{abstract}

The input in the classroom comes especially from the teacher, but there could also be input from the part of the students and audio visual aids used in the teaching process. In that sense using the target language as much as possible, in this case Spanish, would be a benefit for the students, because "It is widely assumed that the use of the target language is one of the crucial variables in the successful acquisition of the target language - the more often students use or practice the second or foreign language, the more likely they are to learn it" (Day 1985, p. 257). It is important to stress at this point that the process involved in studying a foreign language has its acquisition as a goal, rather than merely learning about the language. Krashen (1985) differentiates between both:

There are two independent ways of developing ability in second languages. 'Acquisition' is a subconscious process identical in all important ways to the process children utilize in acquiring their first language, while 'learning' is a conscious process that results in 'knowing about' language (p. 1).

Input from the part of the instructor or other sources is crucial. Nevertheless, we cannot affirm that all types of input would be of great benefit to foreign language students. In this regards, Krashen (1985) proposed the input hypothesis;

The Input Hypothesis claims that humans acquire language in only one way - by understanding messages, or by receiving 'comprehensible input'. We progress along the natural order by understanding input that contains structures at our next stage - structures that are a bit beyond our current level of competence (p. 2). 
Considering this information we see that input should be slightly over the current students' knowledge of the foreign language, which for beginners would be limited, due to their scarce knowledge of the target language. For this reason, the type of speech used by the teacher, as well as the other sources of input may not totally correspond to the actual discourse carried by a native speaker, but this speech will rather be simplified. This simplified speech used by the teacher receives different names, such as "baby talk" and "caretaker speech" (Snow, 1972), but these terms seem more appropriate for children for which reason in this study I will use the term adopted by Ferguson (1971), "foreigner talk". The characteristics of this type of speech are:

The speech that is typically addressed to learners, sometimes called 'foreigner talk', tends to be modified in systematic ways. Among other things, it tends to be slower paced, more clearly enunciated, and syntactically less complex than speech addressed to native speakers or proficient non native speakers' (Allbright \& Bailey 1999, p. 124).

With the use of foreigner talk in the very beginner stage students may understand simple speech without the teacher having to dictate the class in English. Foreigner speech facilitates comprehension and allows students to listen and understand the target language.

Having simplified language, which would be for the most part comprehensible to the student would be the ideal situation for foreign language students, but at the same time students need to know that not every word needs to be understood. Students can realize the meaning of words by paying attention to the entire sentence and the context, or they can ask for clarification. As Wong Fillmore (1985) asserts:

Language learning occurs when students try to figure out what their teachers and classmates are saying, when teachers through their efforts to communicate with learners provide them with enough extra linguistic cues to allow them to figure out what is being said, and when the situation is one that allows learners to make astute guesses at the meaning of the language (p. 35).

In that sense listening is necessary, so that students perceive the meaning of an unknown word from context. Another option, if listening to the context is not enough to grasp the meaning of an utterance is negotiation of meaning. During negotiation in meaning the interlocutors "participants work together to arrive at message comprehension using resources such as comprehension checks, confirmation requests, clarification requests, and so forth" (De la Fuente 2002, p. 83). For this reason, classrooms where negotiation of meaning takes place are conducive to such communicative features. As a matter of fact, Pica (1996) found that "negotiation plays an important role in L2 learning, not by meeting learner's needs directly, but rather as facilitating these two important processes of comprehension and production" (p. 2). Also, Pica (1987) explains in a previous study that negotiated input is more comprehensible than non-negotiated input.

Another reason why negotiation of meaning is important is because it not only enhances understanding, but also enhances the possibility of acquiring L2 production, or in other words, output. As De la Fuente (2002) explains, "Negotiation can promote acquisition because it allows learners to understand words and structures beyond their present level of competence and, eventually, to incorporate them into their L2 production" (p. 83).

We have, then, that the delivery of comprehensible input, as well as effort on the part of the learner to try to understand what is being said, are two important factors in the learning of a second language that can also lead to input's counterpart, output.

The need for studying the topic of L1-L2 alternation in college classrooms is necessary due to several reasons. First, most students studying foreign languages in the United States have not been able to obtain proficiency in the target language (Panetta, 1999; Polio \& Duff, 1994; Wu, 2011) even those who graduate as foreign language majors and become teachers (Polio \& Duff, 1994). In light of the new requirement for foreign language teaching programs to provide national teaching certification to students who have an advanced proficiency level, changes to the traditional forms of teaching foreign languages may be necessary. Finally, "in a global community, foreign language is a necessity, not a luxury" (Nugent 2000, P. 35). 
The purpose of the following paper is to describe and analyze the type of input that a non-native Spanish speaking instructor provides her beginner Spanish students at a private college in the northeast and tries to provide answer the following research questions: What is the ratio of L1-L2 spoken in class? For what functions is each language used? And, are there inconsistencies between teachers' beliefs and classroom practices in regards to the use of English and Spanish?

\section{METHOD}

\section{Participant}

The participant is a female professor in her late thirties. Dr. Flowers (pseudonym) was born in the northeast, in the United States of America. She received a bachelor's degree, master's and $\mathrm{PhD}$ in Spanish from the same institution, a large state university in the northeast. Her interest in the Spanish language started much before college; it started in middle school, when she attended a private Catholic middle school in the same area where she is now teaching. As Dr. Flowers explains: "I started studying Spanish in sixth grade and I loved it. In college I had the opportunity to go to Spain for a semester during my junior year and that increased by much my fluency in Spanish. I even think after that trip I was more fluent than I am now." During her graduate school studies she became a teaching assistant and was in charge of a section of beginners' level each semester. "In graduate school I taught a class each semester, this teaching provided me with experience in teaching and at the same time helped me review vocabulary and grammar. When one teaches one also learns much and it helps you refresh constantly what you learned in the previous years."

Dr. Flowers graduated three years before this study was conducted. After graduation she held different positions in small colleges and universities in the northeast. Currently she is working part time, teaching two sections of the beginners' level. This study is based on four-day observations of one of her classes, described below.

\section{The Beginners Spanish Class}

Students who enrolled in this course were supposed to have no previous knowledge of Spanish. This semester was a continuation of the first part of the beginners level. Therefore, students had already acquired some vocabulary and grammar notions that enabled them to "understand written and spoken Spanish" as it was a goal mentioned in the syllabus.

The lessons centered around a text and a workbook with activities to practice the notions acquired in the text. The activities were mainly designed for students to acquire grammar concepts as well as the pertinent registry. The pace of the course was mainly decided on the amount of material, or chapters, that the class was supposed to cover in this particular semester and this decision of the amount of chapters was not taken by Dr. Flowers but by a committee several years before. This policy had as its goal to have all sections of the same course at more or less the same pace, so that there would not be major differences in the material covered among the different sections of the same level once students passed to the next class, which in this case was the intermediate course, as explained by Dr. Flowers during the interview.

This last half of the beginner's level was expected to cover chapters 7 through 12 of the text. At the time these observations took place the instructor covered all chapter 11. The first session was dedicated to a review of the test from the previous chapter, an overview of chapter 11 and the vocabulary for this chapter. The second session was dedicated to read a historical-geographical reading, as well as a dialogue and a small story that contained the vocabulary for this lesson as well as the grammar concepts for this chapter; the subjunctive. Sessions three and four dealt with the use of the subjunctive and the day after the fourth session the students took the chapter's test. This pattern was followed for each chapter in the text and it was considered that four observations would be the appropriate procedure, so that the typical sequence for a chapter would be observed. 


\section{Data Collection}

This is an instrumental case study and consists of the description, analysis and interpretation of the teaching practices of a Spanish college instructor.

Data were collected through four fifty-minute class observations. The techniques for collecting the data were non-participant class observations, the use of field notes and an interview with the participant.

After initially accepting to have the four sessions tape recorded the second day the instructor manifested her discomfort in having the tape recorder present. For this reason, starting with the second session instead of cassettes the medium for gathering data centered around a checklist in which each sentence expressed was tallied into a category, following Wajnryb's (1992) suggestions for classroom observation tasks. This method allowed the counting of sentences used in each language and the function for which it was intended.

The class observations were performed by keeping a written track of the most relevant aspects that took place in the classroom, such as students attitudes and students way of conducting themselves during the activities, their responses to the teacher's input, the language used in the teacher's responses to the students, etc. During the observations the researcher assumed the role of a non-participant observer, which meant that there was "no involvement with the people or activities studied" (Spradley 1980, p. 59). Dr. Flowers was interviewed following some of Seidman's (1998) guidelines for in-depth phenomenological interviewing. The interview lasted approximately 30 minutes. The information obtained in the interview included Dr. Flowers's life history emphasizing on her educational background and work experience, her beliefs regarding the use of target language versus mother tongue in beginning level courses and the reactions from students towards the amount of target language she used during the years of her teaching experience.

\section{RESULTS}

After counting the times that the instructor used each language, the number of senteces was added, giving the results contained in table 1.

Table 1: Summary Of Teacher's Target Language VS. English And Mixed Sentences

\begin{tabular}{|c|c|c|c|c|c|}
\hline Session & Target Language & English & English Spanish Mixed & Not Understood & Total \\
\hline 1 & 12 & 23 & -- & 1 & 36 \\
\hline 2 & 7 & 21 & 1 & 30 \\
\hline 3 & 9 & 25 & 14 & -- & 35 \\
\hline 4 & 8 & 27 & -- & 1 & 36 \\
\hline Mean & 9 & 24 & 0.5 & 0.75 & 34.25 \\
\hline
\end{tabular}

As we can see in table 1, the instructor spoke mainly English in the classroom, an average of 24 sentences per day, while she spoke an average of 9 sentences in Spanish and only two sentences mixing both languages into one sentence in the four days observed. It is also worth to note that Dr. Flowers continuously used the word "okay", which was initially counted as an English utterance, but later on recorded but not counted as an English word, since this would have increased the number of English words in a disproportionate amount.

These results contrast with the instructor's opinion that she speaks mainly Spanish in the classroom, as expressed in the interview. Seems that Dr. Flowers is not aware of the amount of English she actually speaks in the classroom. After observing the four classes, it became obvious that the classroom speech centered around five main topics, shown in table 2 and further analyzed later in this study. 
Table 2: Summary Of Functions In Which The Teacher Used Only English

\begin{tabular}{|c|c|c|c|c|c|c|}
\hline $\begin{array}{c}\text { Function } \\
\text { Session }\end{array}$ & $\begin{array}{c}\text { Grammar } \\
\text { Explanation }\end{array}$ & $\begin{array}{c}\text { Evaluation } \\
\text { Announcements } \\
\text { Syllabus }\end{array}$ & $\begin{array}{c}\text { Classroom } \\
\text { Management }\end{array}$ & $\begin{array}{c}\text { Isolated Word } \\
\text { Translation }\end{array}$ & Other & Total \\
\hline 1 & 3 & 4 & 5 & 8 & 3 & \\
\hline 2 & 4 & 4 & 6 & 7 & 0 & 23 \\
\hline 3 & 8 & 5 & 3 & 8 & 1 & 21 \\
\hline 4 & 10 & 8 & 3 & 6 & 0 & 27 \\
\hline Total & 25 & 21 & 17 & 29 & 4 & 96 \\
\hline
\end{tabular}

The amount of use of English increased when she taught grammar concepts and translated vocabulary words. At the same time, Spanish was used more often for isolated word translations.

Table 3: Summary Of Functions In Which The Teacher Used Only Spanish

\begin{tabular}{|c|c|c|c|c|c|c|}
\hline $\begin{array}{c}\text { Function } \\
\text { Session }\end{array}$ & $\begin{array}{c}\text { Grammar } \\
\text { Explanation }\end{array}$ & $\begin{array}{c}\text { Evaluation } \\
\text { Announcements } \\
\text { Syllabus }\end{array}$ & $\begin{array}{c}\text { Classroom } \\
\text { Management }\end{array}$ & $\begin{array}{c}\text { Isolated Word } \\
\text { Translation }\end{array}$ & Other & Total \\
\hline 1 & 3 & -- & -- & 7 & 2 & 12 \\
\hline 2 & 2 & 1 & -- & 4 & -- & 7 \\
\hline 3 & 3 & -- & 1 & 4 & 1 & 9 \\
\hline 4 & 4 & -- & 1 & 3 & -- & 8 \\
\hline Total & 12 & 1 & 2 & 18 & 3 & 36 \\
\hline
\end{tabular}

Grammar and isolated words amount for more sentences spoken, but there are several categories besides these two, but for the purpose of this study we will only consider the four more frequently observed: grammar, administrative announcements, class management and isolated words.

For a more specific view of each function and the language in which it was used we will study the different functions separately.

\section{Grammar Explanations}

Based on the information contained in tables 2 and 3, one can notice that Dr. Flowers used twice as much sentences in English as in Spanish. One can also see that the number of grammar sentences increased each day, because of the pattern of approaching each chapter that starts with vocabulary and turns into all grammar for the last two sessions. When asked about her way of approaching the grammar lessons Dr. Flowers expressed; "I tried to use Spanish as much as possible, but if it is a complicated concept and I want to make sure that the students understand I use English". In this case the chapter centered on the use of the subjuctive, which is difficult topic and Dr. Flowers opted by using English most of the time.

The grammar exercises centered around the text and there was no creativity from the part of the students, except when the students did group work activities, but there was only one group activity per session on the third and fourth days.

Something that also called the researcher's attention was the way that the students asked for clarification; they asked in English questions such as "Why is it ... and not ....? What was the answer to number ...?", etc. Those are questions that could be formulated in Spanish and answered in Spanish as well, for which it seems that the use of English may be a habit rather than a necessity.

In this category it was also noticeable that the instructor did almost all the talking, leaving students only to provide specific answers, usually consisting on the conjugation of a verb in the present subjunctive. In that sense, even when reading sentences from the text she mostly read the whole sentence leaving the blank to be filled and said 
by students. This same phenomenon has been previously noticed by researchers. Among them Allwright and Bailey (1991) who mentioned: "Observations of many different classes, both in content area subjects and in language instruction, consistently show that teachers typically do between one half and three quarters of the talking done in classrooms" (p.139). Holmes (1978) mentions the prevalence of this issue: "Research reported from all over the world shows a similar pattern: in India, Belgium, Iraq, South America and New Zealand the teacher keeps on talking" (p. 80).

\section{Evaluation Announcements And Syllabus}

This is the function for which English was almost exclusively used. If we observe tables 2 and 3 we find that from the 22 sentences expressed by the instructor 21 were in English and only one in Spanish. Most of the sentences were short questions and answers. One set of question and answer that took place during the first session, which was the only one that was tape-recorded was the following:

\section{- Student: "When is next test?" \\ - Dr. Flowers: "Wednesday, next week."}

These short sentences could easily had been formulated in Spanish, due to the fact that the students were already aware of this vocabulary, very simplified to be considered "foreigner talk" and still real language communication. Another small dialogue in which we see simple vocabulary, which also took place the first day was:

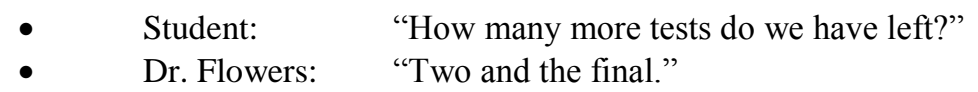

Again, the simplicity of the vocabulary for that answer would have allowed for the use of the target language, especially if we take into account that this information is already known to the students, which is stated in the syllabus in English. When asked regarding the issue of administrative announcements during an informal conversation after the four observations, Dr. Flowers expressed that she usually says announcements in English because "that is not part of the lesson to be learnt for the day", therefore, English was used. This argument shows Dr. Flowers belief that teaching a foreign language can be reduced to grammar and vocabulary lessons, but assuming this position takes away the possibility of establishing real language conversations in the classroom and the practice of familiar vocabulary, such as numbers and days of the week.

\section{Classroom Management}

Under the category "classroom management" are included requests from the instructor for students to open their books, look at a specific page, go to the chalkboard, ask for silence, write answers and related commands. In tables 2 and 3 we see that there were a total of 17 sentences expressed in English and only two in Spanish making this an almost exclusive English expression. Something that is noticeable in this category is that almost all commands given to the students were already studied in a previous chapter, regarding the use of formal commands, and given that Dr. Flowers addresses her students in the formal way, using the pronoun "Ud." the expression of those commands in Spanish would have been a review of the grammar covered the previous chapter. At this point it is important to note that formal commands in Spanish are the same words as the first and third person subjunctive, which was the topic of the chapter to be learned. In this sense the review of such forms through the use of the target language was appropriate.

\section{Isolated Words And Other Functions Of Language}

Isolated words usually referred to the direct translation of vocabulary words and verbs from one language into the other. There were a total of 47 of such translations; given that the readings, dialogues and activities were in Spanish the more common way of translation was from Spanish items into English, a total of 29 of such translations. There were 18 words translated from English into Spanish and those obeyed mainly for grammar activities during the group work of the last two days. For asking for translation students also used English, while the response from the instructor was usually the word translated. 
Finally, the fourth category had other sentences that did not belong to any of the previous categories and were related to empathy, and general questions from the instructor, such as asking for the time, time left and requesting the homework. From those, whenever she asked for the time and time left she spoke English, empathy was done in Spanish and referred to the word "pobrecito" (poor thing) when referring to a student that was not feeling well and homework request was done also in Spanish by using just one word: "Tareas!" (Homework!)

\section{CONCLUSION}

As exemplified in this study, foreign language instructors may not be aware of the large quantity that English is spoken in the classroom. Instructors may not be aware that they are the ones speaking in class for the most part either and for this reason a few suggestions are considered.

It would be of great benefit that future foreign language teachers are video-taped or tape recorded in order to rehearse activities and learn alternative approaches. As Antón (1999) suggested: "Teachers can engage learners in the negotiation of meaning, language forms, and classroom rules by using various discoursive moves, and in so doing can also promote leaner's active mental participation, which may have a role in L2 learning" (p. 305). It is recommendable to require future instructors to take classes in the department of education. If trained into communicatively oriented methods, future teachers may adopt such approaches as their beliefs for language teaching and start a new generation of college instructors that is better prepared for the demands of $21^{\text {st }}$ century foreign language education.

\section{ABOUT THE AUTHOR}

Graziela Rondon-Pari is an Assistant Professor of Spanish at the State University of New York, College at Brockport. Dr. Rondon-Pari obtained a Ph.D. in Foreign and Second Language Education from the University at Buffalo. She also received a MS in Educational Psychology, with a specialization in human learning and a MA in Foreign Languages, specializing in Latin American literature. Both Masters degrees were awarded by Southern Illinois University. She received a Bachelors of Science in Spanish Secondary Education from Universidad Catolica in Peru. Her research interests include: oral and written proficiency assessments, foreign language methodology, error correction research.

\section{REFERENCES}

1. ACTFL (2002). Program Standards for the Preparation of Foreign Language Teachers. Yonkers: NY. The American Council on the Teaching of Foreign Languages.

2. Allbright, D. \& Bailey, K. (1999). Focus in the Language Classroom. Cambridge University Press.

3. Antón, M. (1999). The discourse of learner-centered classroom: Sociocultural perspectives on teacherlearner interaction in the second language classroom. The Modern Language Journal, 83, 303-318.

4. Day, R. (1985). The use of the target language in context and second language proficiency. In S. Gass, \& C. Madden. Input in Second Language Acquisition. Rowley, MA: Newbury House.

5. De la Fuente, M. J. (2002). Negotiation and oral acquisition of L2 vocabulary: The roles of input and output in the receptive and productive acquisition of words. Studies in Second Language Acquisition, 24, 81-112.

6. Ferguson, C. (1971). Absence of copula and the notion of simplicity: a study of normal speech, baby talk, foreigner talk and pidgins. In D. Hymes (ed.). Pidgionization and Creation of Languages. New York: Cambridge University Press.

7. Gass, S. \& Madden, C. (1985). Input in Second Language Acquisition. Rowley, MA: Newbury House.

8. Holmes, J. (1978). Sociolinguistic competence in the classroom. In J. Richards (Ed.) Understanding Second and Foreign Language Learning. Rowley, MA. Newbury House.

9. Horwitz, E. (2008). Becoming a Language Teacher; A Practical guide to Second language Learning and Teaching. New York: Pearson.

10. Krashen, S. (1985). The Input Hypothesis: Issues and Implications. London: Longman.

11. Nugent, S. (2000). Foreign language instruction in a global community NASSP Bulletin, 84, 35-40. 
12. Panetta, L. (1999). Foreign language education: If "scandalous" in the $20^{\text {th }}$ century, what will it be in the $21^{\text {st }}$ century? U.S. Department of Defense.

13. Polio, C. \& Duff, P. (1994). Teachers' Language Use in University foreign language classrooms: A qualitative analysis of English and target language alternation. The Modern Language Journal, 78, 313326.

14. Seidman, I. (1998). Interviewing as Qualitative Research. New York: Teachers College Press.

15. Snow, C. (1972). Mother's speech to children learning language. Child Development, 43 (549-565).

16. Spradley, J. (1980). Participant Observation. Fort Worth: Harcourt Brace College Publishers.

17. Wajnryb, R. (1992). Classroom Observation Tasks. Cambridge (UK): Cambridge University Press.

18. Wong-Fillmore, L. (1985). When does teacher talk work as input? In Susan Gass \& C. Madden (Eds.), Input in Second Language Acquisition (pp. 235-253). Rowley, MA: Newbury House.

19. Wu, P. (2011). The National Standards for Foreign Language Learning: Where's the Beef? A Response to Motivating Students' Foreign Language and Culture Acquisition through Web-Based Inquiry by Levi Altstaedter \& Jones. Foreign Language Annals, 43 (4) 559-562. 